\title{
FAME AFTER LIFE: THE MYSTERY OF EDGAR ALLAN POE'S DEATH
}

\author{
Kirsten Møllegaard
}

\begin{abstract}
Although contemporary legends often deal with the trials and anxieties of everyday life, a considerable body of folk narratives deals with famous historical people and the mysteries, rumors, and anecdotes ascribed to them. American author Edgar Allan Poe (1809-1849) was a trend-setting author of gothic horror and dark mysteries. His short, difficult life and strange death have fueled both academic and folkloristic narratives. Where the academic narratives often analyze his fiction biographically as reflections of his life such as his impoverishment, alcoholism, and frustrated ambition, the folk narratives typically focus on his death at the age of forty. By straddling literary and popular fame, Poe-lore occupies a dynamic Spielraum in contemporary folklore because his haunted life and mysterious death, similar to the literary conventions for the gothic in literature, collapse 'high' and 'low' culture. The folklore of famous people is intimately - perhaps even mysteriously - tied to the perception of individual identity and the social experience of city crowds, strangers, and alienation. In Poe's case, the intertwining of his fiction with his real-life struggles has made Poe scholarship the most biographically centered of any American writer, past or present, and produced Poe not only as a towering legend in American literature, but also as a legendary figure in the popular imagination.
\end{abstract}

Keywords: biography, contemporary legends, death, Edgar Allan Poe, fame, gothic literature, Poe Toaster 
The boundaries which divide Life from Death are at best shadowy and vague. Who shall say where the one ends, and where the other begins? Edgar Allan Poe (2004c: 357)

\section{SITUATING EDGAR ALLAN POE'S FAME IN ACADEMIC AND POPULAR IMAGINATION}

The death, in particular the violent or sudden death, of famous people can produce a new 'life' for them in the popular imagination. They become legendary in the cultural landscape: their lives and accomplishments are sentimentalized or aggrandized; their homes are reverted to shrines and become sites for pilgrimages; their personal effects are prized by collectors and exhibited in museums; their inner lives are continuously analyzed, demonized, embellished, or scrutinized in many types of expressive media (film, books, performances) ranging from scholarly studies to blogs; and their portraits, signature artifacts, and photographic poses are visually branded onto objects of material culture through the endless process of copying, printing, and re-printing images on commercial merchandise and souvenirs. In Celebrity, sociologist Chris Rojek observes, "The fact that media representation is the basis of celebrity is at the heart of both the question of the mysterious tenacity of celebrity power and the peculiar fragility of celebrity presence" (2001: 16). Media-driven post-mortem fame may in fact overshadow the level of fame, or popular celebrity, the person achieved while alive. This is certainly the case for the American author Edgar Allan Poe (1809-1849), whose afterlife in both academia and popular culture includes an impressive corpus of belief narratives surrounding his death, which overshadow the level of his fame in real life. Today Poe is considered the founder of the detective genre, the master of gothic horror, and the most influential American writer of the Romantic Movement. His works include the classics The Raven, The Fall of the House of Usher, the Dupin murder mysteries, The Pit and the Pendulum, The Premature Burial, The Tell-Tale Heart, The Black Cat, The Gold Bug, The Cask of Amontillado, The Masque of Red Death, and many other gothic tales of dark mysteries, horror, madness, and spectacular violence.

No other American writer has had as enduring and pervasive an influence on popular culture as Poe has. To claim that "everybody knows Poe", as J. W. Ocker does in Poe-Land: The Hallowed Haunts of Edgar Allan Poe (2015: 10 ), is hyperbole, but not entirely false either. Poe's fame uniquely spans from the ivory tower of academia to the gutters of $B$ horror movies. To mention a few 


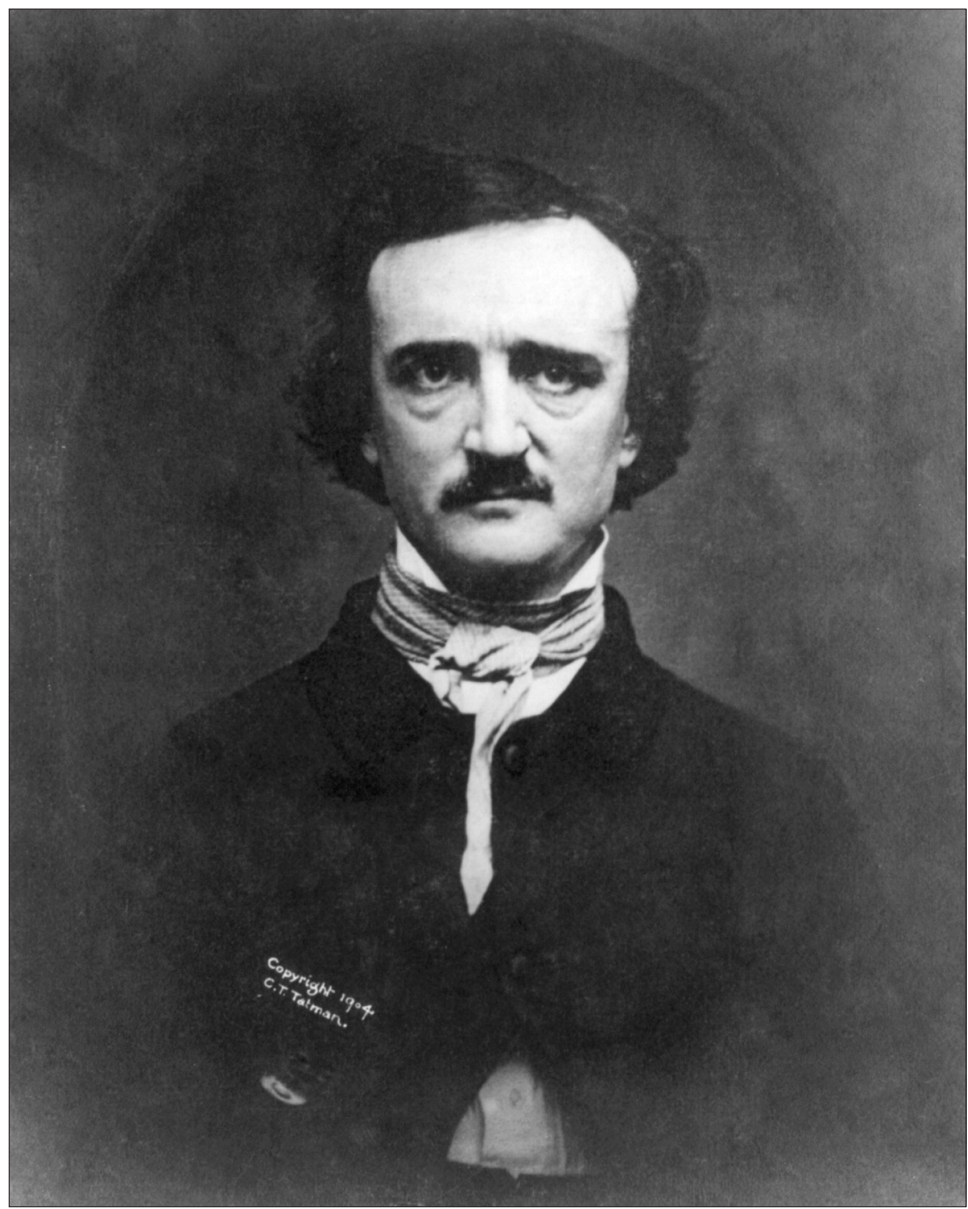

Figure 1. Edgar Allan Poe, 1848. Photograph by W. S. Hartshorn (http: / / www.loc.gov/pictures / item / 2004672796/).

examples that illustrate "Poe's ambiguous position between highbrow and lowbrow culture" (Neimeyer 2002: 208): busts and statues of Poe alongside other canonized literati adorn learned institutions and libraries across the US, but out of all those celebrated writers only his image appears on the cover of The Beatles' 1967 album Sgt. Pepper's Lonely Hearts Club Band; a National Football League team, the Baltimore Ravens, takes its name and logo from Poe's poem The Raven; cartoon characters like Garfield and Bart Simpson have recited Poe's works; many horror films, including B-movie cult classics starring Vincent Price, draw their inspiration from Poe's works; the US postal service has issued 
two commemorative stamps of Poe in 1949 and 2009; women's magazines like Better Homes and Gardens give seasonal advice on how to make a Poe-inspired Halloween dinner; original Poe memorabilia, letters, and manuscripts fetch sixand seven-digit prices at auctions, while mass-produced souvenirs like coffee mugs, refrigerator magnets, baby bibs, and mouse pads sell for considerably less. The list goes on, and so does Poe's afterlife, as expressed by a devoted fan: "Never RIP, Edgar Allan Poe" (Ocker 2015: 360).

Poe's dynamic afterlife is fueled by two seemingly incongruous, yet mutually influential forces: Poe's tenacious popularity and visual presence in pop culture, and his canonized influence on literary genre, which ensures that every American high school student will have read some of his works, most commonly The Raven and The Fall of the House of Usher. Since the focus of this article is on Poe as a haunting presence in the popular imagination, there will be no attempt to separate the "academic Poe and the pop-culture Poe" (Peeples 2004: 125). Rather, this article will investigate the overlap between the folkloric and the academic in the narratives surrounding Poe's death and, broadly speaking, consider how popular fascination with fame contributes to the production of contemporary folklore. Poe-lore is invested with social fears of death and desires for fame; it hovers precariously between actual events and the signifying practices of storytelling; and, when seen as an example of Michel de Certeau's outline of discourse formation, Poe-lore authorizes a Spielraum (room for free play) in the popular imagination for negotiating the knowable, the mysterious, and the poetic in everyday life (Certeau 1984: 91-114).

As Jan Bondeson argues in Buried Alive: The Terrifying History of Our Most Primal Fear, Poe drew generously on folktales and legends in his horror stories. Bondeson even declares that the theme of premature burial was an 'unwholesome fascination' and 'obsession' for Poe (2001: 208, 214). In general, writers do of course draw on material from everyday life for their literary endeavors, but Bondeson's remarks serve as an important reminder that Poe's fame is intertwined with a perceived image of him in the public sphere as mentally deranged, mysteriously dark, unwholesome, and obsessed with morbid themes, while he is celebrated in scholarly circles for his originality and generic innovations.

Poe's fame is thus situated in the dynamic realm of the popular (including popular literature), where there is "contestation between various cultural forces in which hegemony and resistance, conformity and subversion, may be produced" (original emphasis, Blanco \& Peeren 2010: xii). The tension between those contesting cultural forces energizes both Poe scholarship and Poe's continuing presence in popular urban legends, rituals, and performances. However, scholars primarily see celebrity as "a modern phenomenon, a phenomenon of mass-circulation newspapers, TV, radio and film” (Rojek 2001: 16). Norbert 
Ruebsaat contends, "Celebrity, as we know it today, was created by modern mass media" (2007: 9). However, today's media-driven celebrity cult is historically related to the production of rumors, legends, tall tales, and similar folk narratives. Like contemporary legends, narratives about famous people "are told as true, or at best plausible, and ... are mirrors of cultural values" (Møllegaard 2005: 41). The social production of Poe's fame is thus intimately related to the folkloric aspect of urban and contemporary legends because fame hinges on the telling of stories that, for better or worse, are "too good to be true" (Brunvand 1999: 19). Fame as well as ill fame is associated with narrative processes in general and with telling stories in particular. In Roman mythology, the goddess Fama (Pheme in Greek mythology) personified rumor, gossip, and endless curiosity about the lives of others. In The Aeneid, book IV, Vergil describes Fama as a winged creature with many eyes, ears, and wagging tongues. Fama is not concerned with what is true or false: "Her claws hold both true news and evil lies. / She filled the realms now with her tangled talk, / chanting in glee a mix of fact and fiction" (Vergil 2008, lines 188-190). According to the Oxford English Dictionary, the root words for the Greek name Pheme and the Latin Fama relate to the derivative colloquial word for 'speak' or 'talk', fabulare (OED 1989: 703-704). This etymology suggests that fame is a multifaceted concept, which includes, on the positive side, public renown, good reputation, and celebrity as means to achieve high social status and, on the negative side, ill fame, scandal, and bad reputation, and consequently the expulsion from 'good' society.

Poe's posthumous fame is not only media-driven; it is also performative and informed by vernacular expressions of folk beliefs and folklife (chiefly in the form of tourism). Although Poe lived in an era far removed from contemporary reputation generators like the tabloid press, blogs, Twitter, Facebook, etc., rumors and anecdotes that related facts or fiction about a person's good or bad reputation - either in print or by word of mouth - were powerful social tools of control in antebellum USA. In his lifetime, Poe was considered a controversial figure in literary circles. He was not uniformly recognized as a literary genius although he actively tried to become a famous writer. As Mark Neimeyer points out, Poe "clearly, though largely unsuccessfully, sought popular success during his lifetime" (2002: 207). Scott Peeples acknowledges that "certainly Poe was alert to the way reputations are manufactured" (2004: 25), but he also notes that Poe's irrational, confrontational behavior often undermined his own best interests. Suggestive as these remarks are about Poe's own agency in fabricating a public reputation, it is important to recognize that Poe's public persona and his astounding posthumous fame as the enfant terrible of American letters were produced, and continue to be produced, by a combination of scholarly and lay interest in his life and works. 
Some scholars attribute Poe's posthumous fame to his proverbial self-destructiveness, that is, his self-identified "imp of the perverse", which is the urge to "do wrong for wrong's sake only" (Poe 2004b [1840]: 350). J. Gerald Kennedy captures the essence of Poe's reputation when stating that Poe's "sheer perverseness, his urge to locate and confront enemies, to offend and disgust, to mock and mystify, ensured that Poe would remain (as on some level he desired) the obnoxious misfit of American letters, the bad boy of the antebellum literary world" (Kennedy 1996: 535). Virtually all Poe scholars agree that Poe's successor as editor of Graham's Magazine, Rufus Griswold, committed character assassination against Poe immediately after his death by writing a scathing, vindictive obituary describing Poe as dishonest, alcoholic, immoral, mentally deranged, conceited, decadent, and without friends (Peeples 2004: 2). Ironically, it seems, Griswold's defamation of Poe launched the so-called 'Poe Legend' and thus contributed to Poe's posthumous fame in significant ways (Ljungquist 2002: 7).

\section{A BRIEF OUTLINE OF POE'S LIFE}

In order to situate the legends about Poe's death in a biographical context, a brief synopsis of his life and literary themes is in order. Edgar Poe was born in Boston, MA, to itinerant actors on January 19, 1809. In 1811, his father David Poe abandoned the family and died a year later, leaving wife Elizabeth Arnold Poe destitute with three young children: Henry, Edgar, and Rosalie. Elizabeth died of tuberculosis in Richmond, VA, just before Christmas in 1811, when Edgar was two years old. The children were divided up amongst foster families. Edgar was taken in by a wealthy tobacco merchant, John Allan and his wife Frances, and his name was legally changed to Edgar Allan Poe. Poe grew up in relative affluence, but as he grew into manhood, he and John Allan developed an increasingly contentious relationship and fought over money. In 1827 Poe's foster mother Frances died of tuberculosis. At the age of twenty, Poe was completely estranged from his foster family and virtually penniless. He had to quit University of Virginia after one semester, and after a two-year stint in the army at West Point, he became an editor and literary critic and tried to make a living as a writer. When he was twenty-seven, he married his thirteen-year-old cousin Virginia Clemm. She died of tuberculosis twelve years later, in 1847. They had no children. Although Poe had difficulty getting his work published and never made much of a profit from it - for example, he only earned $\$ 9.00$ from his masterpiece poem The Raven - his poetry and short stories were 
in fact well received during his lifetime. The death of the three women closest to him from tuberculosis - his mother, foster mother, and wife - is a vital part of the tragic aura of his biography; but it is also an essential element of his philosophy of composition and underlies his famous dictum, "the death, then, of a beautiful woman is, unquestionably, the most poetical topic in the world" (Poe 2004e [1845]: 680).

Poe's life was emotionally difficult, financially turbulent, and marked by periods of sobriety alternating with periods of excessive drinking, manic behavior, and possible drug use. He fought with editors and had trouble keeping a job. The Poe household included Edgar, Virginia, and her mother Maria Clemm. They moved frequently. Their living quarters have been traced to several addresses in Baltimore, Richmond, Philadelphia, and New York. Poe was very much an urbanite, and many of his most haunting short stories - for example, The Man of the Crowd, The Murders in the Rue Morgue, and The Imp of the Perverse - evoke the social experience of urban space and crowds, menacing strangers, and existential alienation in the city.

Poe's fictional cityscapes are fraught with existential chasms of Angst, conjuring ghostly shadows and imaginary geographies haunted by death. In The Imp of the Perverse, for example, the narrator, who is basking in felicity over having committed a cruel murder and gotten away with it, is walking down a busy street when he is suddenly overcome by paranoia. He thinks he sees the ghost of the man he murdered. Terrified, he starts running: "I bounded like a madman through the crowded thoroughfares. But now the populace took alarm and pursued" (Poe 2004d [1845]: 406). He is roughly detained by the crowd and hysterically blurts out his confession. Similarly, the claustrophobic squeeze of crowds upsets the narrator in The Man of the Crowd, who observes how "dense and continuous tides of population were rushing past the door" (Poe 2004a [1845]: 233). He spends the night obsessively following an old man through filthy labyrinthine streets, in the rain, in a nightmarish attempt to escape the crowds by becoming swallowed up in the whirlpool of humanity. Poe's fiction in general is haunted by images of death, madness, and violence, but his dark cityscapes loom large over the legends and theories that attempt to explain how Poe died. Fatefully, Poe's own death in Baltimore appears to have been framed exactly as he envisioned in his fiction by a maelstrom of busy, dirty streets, rough-handed struggle, and mental torment.

Poe's death at the age of forty, in 1849, has been the subject of intense debate and speculation, spawning not only a large number of scholarly books and papers, but also inspiring an annual nocturnal ritual by a disguised agent known as the Poe Toaster. 


\section{POE'S DEATH: FACTS AND THEORIES}

The elusive search for what caused Poe's death has generated many types of narratives and a great deal of media interest. Some narratives build on thorough archival investigations, others attempt to glean a medical diagnosis from the fragmentary documents describing Poe's final days, and some are mainly speculative. While the scholarly production of narratives pertaining to Poe's death is both ingenious and in many instances very well argued, to this day it remains inconclusive what exactly Poe died of.

What is known for a fact is that Poe had left Richmond, VA, for Philadelphia, PA, on September 27, 1849. There is no verifiable evidence about his whereabouts or activities between September 27 and October 3, 1849, when he was found semiconscious and delirious in front of a voting poll in Baltimore, $\mathrm{MD}$, dressed in ill-fitting clothes not his own. An urgent note from a printer named Joseph Walker to Dr. Joseph Evan Snodgrass at Washington College Hospital states, “There is a gentleman rather the worse for wear, at Ryan's 4th ward polls, who goes under the cognomen of Edgar A. Poe, and who appears in great distress \& says he is acquainted with you, he is in need of immediate assistance" (Thomas \& Jackson 1987: 844). Four days later, on October 7, 1849, Poe died at the hospital.

There are several accounts about what transpired between Poe being found at Ryan's tavern and his death at the hospital, but they are not entirely clear. Dr. Snodgrass went to the polling station and immediately recognized Poe's face, "although it wore an aspect of vacant stupidity that made me shudder" (Thomas \& Jackson 1987: 844). Dr. Snodgrass tried to procure a room for Poe at the tavern, but the innkeeper refused to accommodate him due to Poe's "abusive and ungrateful" behavior (ibid.). Poe was sent to the Washington College Hospital. Dr. Snodgrass relates, "So insensible was he, that we had to carry him to the carriage as if a corpse. The muscles of articulation seemed paralyzed to speechlessness, and mere incoherent mutterings were all that were heard" (Thomas \& Jackson 1987: 845). Dr. Snodgrass' testimony comes from his article Death and Burial of Edgar A. Poe, which was published in May 1856, seven years after Poe's death. Dr. Snodgrass appears to have muddied the clarity of what transpired at the hospital. Robert Hopkins explains that Dr. Snodgrass was a strong proponent of temperance and "a religious zealot who, from the early 1850s, preached the gospel of Poe's death as a result of the sin of a dissolute life as a drunkard" (2007: 43). To warn against the ill effects of alcohol, he even falsified the content of Walker's emergency note in order to present Poe's condition as the result of overconsumption of alcohol: "whereas Walker spoke of a 'Gentleman, rather the worse for wear,' Snodgrass substituted 'in a state of beastly intoxication"' (Brandy 1987). 
At the hospital, Poe was erratic and had to be restrained. Dr. John J. Moran, the resident physician, reported that on the fourth day Poe called out for someone named Reynolds, the identity of whom is not known, though some scholars believe that Poe alluded to Jeremiah N. Reynolds, the South Sea explorer, whose travel accounts had inspired Poe to write his only novel, The Narrative of Arthur Gordon Pym of Nantucket (1838), (Walsh 1999: 122). On October 7, Poe said a short prayer - "Lord, help my poor soul" - before he died. Dr. Moran related this account in a letter dated November 15, 1849, to Poe's mother-in-law Maria Clemm. He concluded that Poe died from delirium tremens. According to Dr. Moran, Poe was beset by violent deliriums, at one point saying that "the best thing his friends could do would be to blow out his brains with a pistol" (Thomas \& Jackson 1987: 846). However, W. T. Brandy questions Dr. Moran's trustworthiness (Brandy 1987). Dr. Moran later went on speaking tours and published articles, in which he changed and embellished many of the statements he had initially made in the letter to Mrs. Clemms. Kenneth Silverman sums up:

The cause of Poe's death remains in doubt. Moran's account of his profuse perspiration, trembling, and hallucinations indicates delirium tremens, mania à potu. Many others who had known Poe, including the professionally trained Dr. Snodgrass, also attributed his death to a lethal amount of alcohol. Moran later vigorously disputed this explanation, however, and some Baltimore newspapers gave the cause of death as "congestion of the brain" or "cerebral inflammation." Although the terms were sometimes used euphemistically in public announcements of deaths from disgraceful causes, such as alcoholism, they may in this case have come from the hospital staff itself. According to Moran, one of its senior physicians diagnosed Poe's condition as encephalitis, a brain inflammation, brought on by exposure. (1991: 435-436)

No autopsy was performed, and Poe was buried in an unmarked grave at Westminster Hall and Burying Ground in Baltimore two days later, on October 9, 1849. Today, a headstone marks this spot. Twenty-six years later, in 1875, Poe's remains were moved to a new prominent grave in front of the church. Ten years after that, in 1885, the remains of his wife Virginia, who had been buried in New York, and mother-in-law Maria, who had died in 1871, were also placed in the new grave. The imposing monument that marks this grave is where the so-called Poe Toaster, who will be discussed below, for fifty years placed three red roses and an opened bottle of cognac on Poe's birthday, January 19.

Poe's pauper burial and the cryptic death diagnosis, congestion of the brain, have given rise to considerable speculation about what actually caused Poe's death. The Edgar Alan Poe Museum in Richmond offers a comprehensive, though not exhaustive, chronological list of proposed theories of Poe's death 
cause and the year they were proposed: beating (1857), epilepsy (1875), dipsomania (1921), heart disease (1926), toxic disorder (1970), diabetes (1977), hypoglycemia (1979), alcohol dehydrogenase (1984), porphyria (1989), delirium tremens (1992), rabies (1996), heart attack (1997), murder (1998), epilepsy (1999), carbon monoxide poisoning (1999), and brain tumor (2007) (Museum 2014). Considering the rather long-term progression of some of these diseases and conditions, it is remarkable that Poe wrote in a letter the year before his death: "My health is better - best. I have never been so well" (cited in Kennedy 2001: 55).

An Internet search produces multiple websites speculating on the possible causes of Poe's death in both scholarly databases and popular websites. The scholarly sources tend to include detective work in Poe's papers and letters, along with examination of his contemporaries' letters. However, even in the scholarly sources there happens to be a rather laissez-faire use of medical terminology, resulting in some bizarre diagnoses of what caused Poe's death. Hopkins, for example, refers to the possibility that Poe suffered from "sclerosis of the liver" (2007: 42), possibly confusing sclerosis with cirrhosis. Beyond aca-

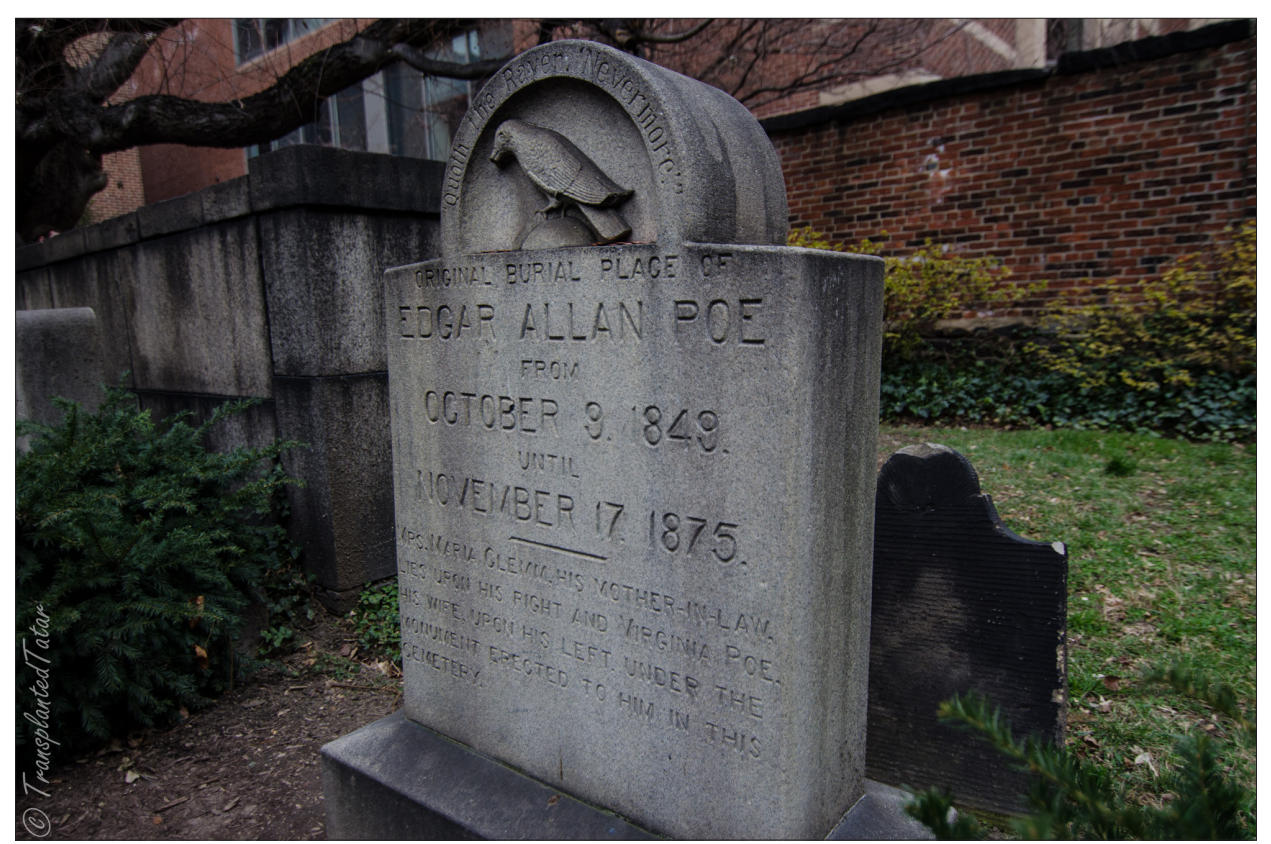

Figure 2. Poe's original grave. Westminster Hall and Burying Ground, Baltimore, MD (https: / / transplantedtatar.com/2013/04/01/poe-amontillado-wine-tasting-201 /). 
demic databases, in more accessible venues like Wikipedia and Open Culture, for example, speculations about Poe's death include - in addition to the causes just mentioned - suicide, murder, cholera, influenza, and cooping as possible causes for his death. Cooping refers to the 19th century practice in American politics of forcing a person to vote, under the threat of violence or the effects of drugs or alcohol, often several times, for the same candidate. Since cooping often involved changing the cooped person's clothes so that he might pass for someone else, this theory addresses the mystery of why Poe was wearing someone else's clothes when he was found at the tavern polling station.

All these speculations over the last 150 years have contributed to the scholarly lore of American literary biography. From a folklore perspective the circulation and consumption of these theories provide a case study of the mysteries and anxieties associated with the confluence of famous people and the urban gothic in everyday culture. "Poe's death is one of the biggest literary mysteries, period," argues Matthew Pearl in an interview with The Observer. "People don't grow tired of it. It's sort of like the J.F.K. assassination" (Neyfakh 2007). Pearl, by the way, believes that Poe died from a brain tumor.

Pearl's reference to the 1963 assassination of President John F. Kennedy is an important clue to understanding why Poe's death continues to fascinate scholars. The violent death of famous people elevates them to emblems of tragedy in the public imagination. In a study on the popular deification of Princess Diana by Gillian Bennett and Anne Rowbottom (2009), the authors identify the dual forces of news media and folk sentiments as driving the modern-day hagiography of figures like Grace Kelly, Elvis Presley, Eva Peron, James Dean, Marilyn Monroe, and Jimi Hendrix. In Poe's case, however, the news media tend to play a secondary role compared to the power of sentimental scholarly, perhaps pseudo-scholarly, investment in mystifying Poe's death. For example, while his death at the age of forty is often seen as suspicious and tragic, life expectancy for white American males in 1850 was actually only 38.3 years (Life Expectancy 2007). The sensationalism with which these death theories are launched, complete with morbid details, tends to fuel and romanticize rather than solve the mystery of Poe's death. For example, Pearl's theory that Poe died of a cancerous brain tumor is based on newspaper articles printed one to three years after Poe's remains had been reburied, that is, twenty-seven to twenty-nine years after he died. The state of his remains would likely have deteriorated considerably, but witnesses to the reburial stated that Poe's brain was still visible inside the skull and looked "dried and hardened" (Harris 2007). Pearl relates that "one account described the brain as almost rattling around inside Poe's head" (ibid.). After consulting a friend whose wife is a doctor, Pearl concludes that Poe died from a brain tumor that had calcified after his death. 
It needs mentioning that scholars who launch sensational theories about Poe's death may be motivated by pecuniary interests. Pearl's novel, The Poe Shadow (2007), received mediocre reviews, but because of the popular interest in anything pertaining to Poe's melodramatic life, Pearl was interviewed in leading newspapers in the United Kingdom and the United States and thus able to promote his book.

More in the vein of occultism, in the years after Poe's death there were rumors claiming that the author's spirit posthumously tried to contact Sarah Helen Whitman, a woman with whom he was romantically involved in the last couple of years of his life. Whitman supposedly hired a psychic medium, Lizzie Doten, who published poetry she claimed Poe's ghost had dictated to her fourteen years after his death. More recently, efforts to vindicate Poe's reputation as an alcoholic have prevailed. In addition to wooing Whitman, Poe had a romantic liaison with the wealthy widow Sarah Elmira Royster Shelton, with whom he purportedly was engaged to be married in 1849 (Walsh 1999: 106-123). Based on rumors that Shelton's family opposed her plans to marry Poe, historian John Evangelist Walsh proposes that Shelton's three brothers went to Baltimore, restrained and plied a sober Poe with alcohol, dressed him in someone else's clothes to make him look like a victim of cooping, and left him in dire condition at the tavern, where Dr. Snodgrass later recovered him.

\section{THE POE TOASTER}

Scott Peeples observes:

Scholars in recent years have been paying more attention to what might be called 'the Poe effect', the creation and maintenance of Poe's image, the various ways this image interacts with popular culture and with Poe's writing. As Mark Neimeyer puts it, 'the popular exploitation of Poe can be seen as adding another dimension to the element of the uncanny already present in the author's writings since these productions are all strangely Poe and not Poe at the same time' (222). (2004: 126)

The mysterious Poe Toaster is one the most dynamic and performative aspects of the Poe Legend (the corpus of narratives pertaining to his life and works) and its effect on popular culture. The Poe Toaster began a ritual of toasting Poe at his grave on the night of January 19, Poe's birthday, and leaving an open bottle of cognac along with three roses. This ceremony has been recorded with some uncertainty back to 1949, the centennial of Poe's death (Society n.d.). It ended 
in 2009, the 150th anniversary of Poe's death. Although there are numerous Poe performers (Ocker 2015: 25), who dress up as Poe and read his works or who act in Poe-inspired performances, such enacted performances are different from the spectrum of folklore dynamism surrounding the media-named Poe Toaster (Toelken 1996: 40-43). The Poe Toaster's annual ritual draws on the traditional perception of Poe as a man of mystery, death, and horror, by adding another layer of mystery to his name and death. The ritual's site is clearly significant: Poe's grave contains not only the great poet's earthly remains, but also his aura. Weirdly uncanny to modern sensibilities, he rests there with his wife/cousin and mother-in-law/aunt. As a cultural marker, the Poe monument is a tourist attraction and a highly visual landmark in Baltimore. A wooden engraving depicting its unveiling in 1875 shows a woman placing a wreath adorned with a raven on top of the monument, a rite that establishes a clear symbolic connection between the black raven, a bird often associated with wisdom, death, and graveyards in popular culture, and Poe, whose most famous poem is, of course, The Raven (Society n.d.).

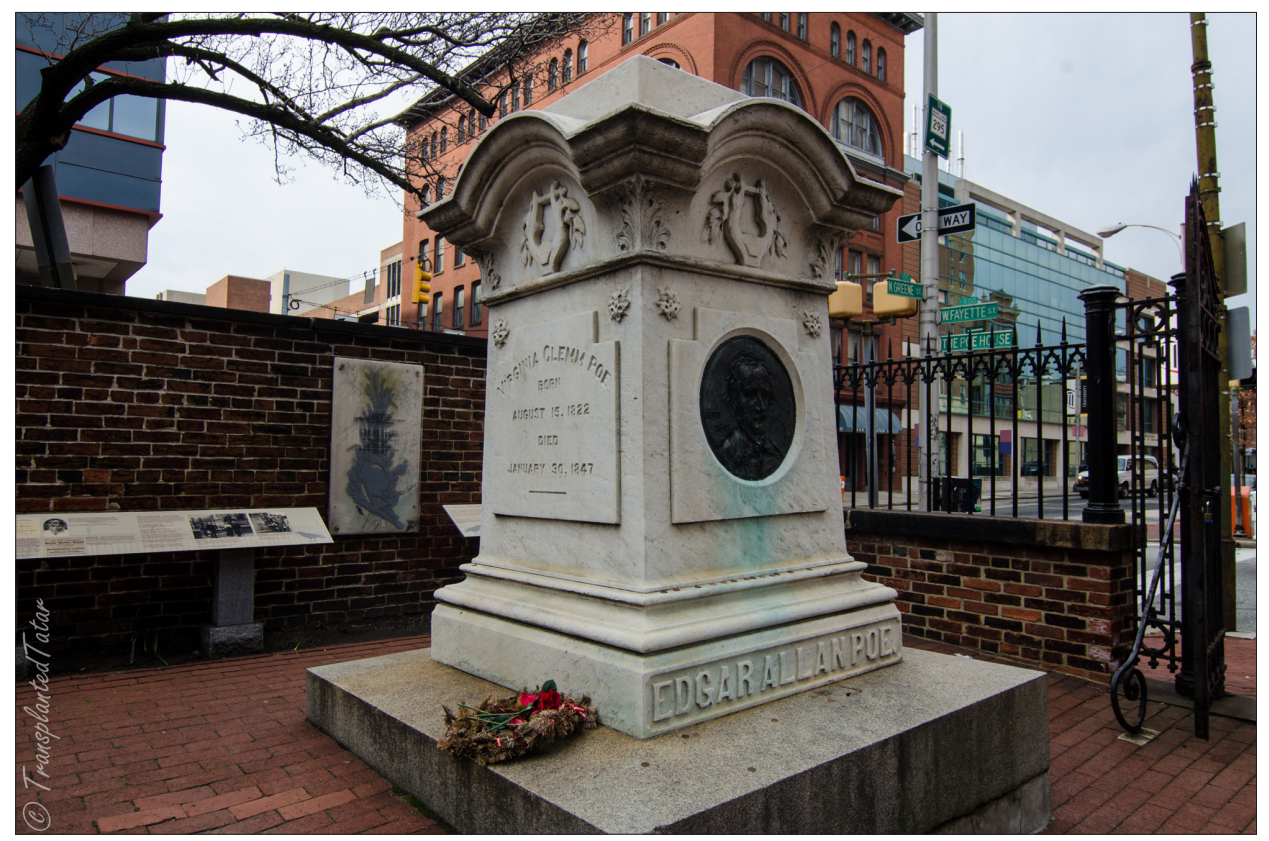

Figure 3. Poe monument. Westminster Hall and Burying Ground, Baltimore, MD (https: / / transplantedtatar.com/2013/04/01 / poe-amontillado-wine-tasting-201 /). 
To this day, Poe's grave inspires feelings of eeriness and the occult in visitors. Blogs on the TripAdvisor website contain visitors' statements illustrating how the belief narratives about Poe, his fame, and the mystery surrounding his name are continuously reproduced and retold by visitors who do not have a scholarly interest in Poe's works, but who nevertheless make the pilgrimage to his gravesite. One person advises that "the best evening to visit is on Poes Birthday [sic]. Yes, spirits do come alive and yes, spirits do return!! The catacomb is the most unique, erie [sic] and spiritual realm where both Poe and Annabel are buried. Your emotions will be on Edge [sic]!" (TripAdvisor 2015). This writer confuses Poe's burial place with the nearby church catacomb, and Poe's wife Virginia with the titular character in his love poem Annabel Lee. Another visitor feels overwhelmed with the amount of information displayed on plaques: "Is it a grave? Is it a monument? Is it a memorial? There are several signs with way too much info about the site, which made it confusing. It's interesting though" (ibid.). Despite this apparent confusion, the visitor had reason to conclude that the gravesite is interesting and worth the effort to see. Confusion as to where Poe is buried is also part of the visitor experience:

There are 2 cemetery stones for Poe, one is memorial and [the] other is his grave site [sic]. The huge memorial stone is made from fan [sic] and community to honor him. If you want to check his actual grave site, it at [sic] around the building and his grave stone is old and normal. It was cool to see these. (ibid.)

"Why is Poe so cool?" asks Ocker (2015: 30). The mystery surrounding Poe's name and his prominent position in both academics and pop culture make it both 'cool' and 'interesting' for visitors to revere his grave in Baltimore as one of the city's greatest tourist sites. The Poe Toaster, however, has not received much academic attention, but this shadowy figure is without doubt a central element in the Poe Legend's folkloristic appeal.

The stealthy, shrouded Poe Toaster has the characteristics of a sly folk hero, partly a trickster to the adoring crowds of Poe devotees, and partly a loyal fan to Poe's memory. The melodramatic performance of toasting Poe and leaving three red roses and the rest of the cognac at the monument has quasi-religious overtones that suggest a parallel to the symbolic role of sacramental wine in liturgical rites with the number three mirroring the holy trinity. The persistence of the ritual over fifty years contributes to its perceived authenticity. The anonymity of the Toaster has spawned its own set of rumors, including the suggestion that the identity is known by the Edgar Allan Poe Society of Baltimore, and even that the Toaster ritual is enacted by a member of the Poe 
Society. The Society vehemently denies these allegations, but nevertheless appears to be certain that the Toaster is a man, though not necessarily the same man over the years. The website explains:

A note left for Jeff Jerome [curator of the Poe Society of Baltimore] in 1993 stated somewhat cryptically that "the torch will be passed," and another note left in 1999 indicated that the original "Toaster" had died within a few months before the annual event. After 1993, sightings of the visitor suggested two younger persons were exchanging the obligation between themselves, presumably in honor of their father. (Society n.d.)

Interestingly, the Edgar Allan Poe Society of Baltimore seems to endorse this apparent family tradition of toasting Poe. In contrast, it regards recent Toasters, i.e. those appearing after 2009, as "faux Toasters":

As there is no authoritative body other than the person who appears to have originated the tradition, and those he has designated, and no such transfer of authority has occurred, all such attempts to restart a new tradition must be taken purely on their own merits. (ibid.)

Numerous attempts have been made over the years to detain or photograph the Toaster. Life Magazine published a blurry picture of a male figure kneeling by the Poe monument in July 1990, but whether it actually depicts the Toaster has never been fully verified.

These activities and performances have become immersed in Baltimore's public profile as a unique tradition. Maryland Public Television has devoted a website titled Knowing Poe to the Poe Legend, complete with resources on Poe for schoolteachers and the general public. Here we learn:

One of Baltimore's spookiest traditions occurs every year on January 19, Poe's birthday, at the cemetery where the famous author is buried. A mysterious man steps out of the shadows at the Westminster Church Yard, wearing a black coat and hat, with a scarf covering his face. He stops at Poe's grave, and leaves a half-full bottle of cognac and three roses. Then he steals away into the darkness. No one knows who the man is or why he enacts this tribute to Poe year after year. Over time, he has simply become known as "the Poe Toaster," a reference to the toast (of cognac) that he seems to be offering Poe. The roses he leaves are believed to be in memory of the three persons buried at the site of the Poe Monument: Poe, Maria Clemm, and Virginia Poe. (Knowing Poe 2002) 
To put a broader perspective on the Poe Legend, the lionizing of Poe has a mythical structure in the sense that Michel de Certeau employs the term 'myth' to mean "a discourse relative to the place/nowhere of concrete existence" (1984: 102). The Toaster's symbolic ritual has become known for its media effect rather than for its ceremonial significance. It exoticizes a monument over a dead writer by charging it with mystery. As de Certeau points out, "stories ... carry out a labor that constantly transforms places into spaces or spaces into places" (ibid.: 118). The Poe monument in Baltimore has become such a charged space. For Poe fans and tourists, it is a pilgrimage site. It is haunted not only by its own history, but also by the cultural imaginary surrounding Poe's name and legacy as a tragic figure, a brilliant writer who struggled against his own vices, his foes and demons, while the women he loved the most - his mother Eliza, his foster mother Frances Allan, and his young wife Virginia - died slow, painful deaths from tuberculosis.

\section{BELIEF NARRATIVES IN A NATIONAL CONTEXT}

Poe's short, turbulent life and the strange circumstances of his death have fueled both academic and folkloristic narratives. Where the academic narratives mainly analyze his fiction biographically, as reflections of his life experiences, such as his upbringing as a foster child, life-long impoverishment, bouts of substance abuse, literary brilliance, and frustrated ambition, the folk narratives typically focus on dark romantic mysteries, especially his fascination with pale, dying women, and the personal losses he suffered. The academic studies and folkloristic belief narratives surrounding Poe's demise have many belief elements in common, which validate Linda Dégh's observation that "the legend is a legend once it entertains debate about belief. Short or long, complete or rudimentary, local or global, supernatural, horrible, mysterious, or grotesque, about one's own or someone else's experience, the sounding of contrary opinions is what makes a legend a legend" (Dégh 2001: 97).

Dégh's definition of a legend as a debatable narrative, one in which opposing beliefs and contrary points of view come into play in the dynamic Spielraum identified by Certeau, provides a meaningful framework for considering narratives about Poe's death. Other concepts from folklore studies are also helpful for understanding the Poe phenomenon. 'Urban legend' is a popular term, though really a misnomer, for the types of informal stories told as true about strange occurrences that happen in everyday situations. Folklore scholars refer to them as 'contemporary' rather than 'urban' legends because they do not always take place in an urban setting; however, since narratives about Poe's death in fact are situated in cities and specifically are reflective of the anxieties and desires 
associated with urban living, the terms 'contemporary' and 'urban' are used interchangeably here. Diane E. Goldstein sums up the main tenants of contemporary legends:

They are told as true, factual, or plausible and therefore assume a level of authority; they provoke dialogue about the narrative events, their interpretation, and their plausibility; they both articulate and influence beliefs and attitudes towards the subject matter; and they have the capability of affecting the actions and behavior of the listening audience. (2004: 28)

It is often assumed that only so-called ordinary people produce and believe in contemporary legends. This assumption leans on the romantic idea of the common Volk as generating a rich repertoire of oral narratives, which the discerning minds of scholars presumably are exempted from believing to be true. In reality, scholars partake in the folklore process by producing narratives, predominantly in writing, that are imaginative and legendary in nature, though often parading as erudite fact, or, at best, arguing an interpretative point.

The task of identifying the beliefs behind Poe's posthumous fame, however, is complex. Folk beliefs do not exist in a socio-cultural vacuum. Rather, they reflect social values and traditions over time. Alan Dundes reminds us that "the term 'folk' can refer to any group of people whatsoever who share at least one common factor.... A member of the group may not know all other members, but he will probably know the common core of traditions belonging to the group, traditions which help the group have a sense of group identity" (1965: 2, original emphasis). The folk groups (which include the academics that study Poe's works) invested in uncovering the cause of Poe's death are a motley crew; this article does not attempt to profile them other than to make two general observations: one, that they typically draw their inspiration from older traditions of Poe-lore (ostensibly in order to revise them, thus engaging in a dialogue with tradition) and, two, that they perceive Poe to be an emblematic figure in defining the American experience.

Concerns about national identity play a significant role in mapping the folk traditions surrounding Poe. In an insightful analysis of Poe's place in American letters, Scott Peeples traces how American critics have attempted to appropriate Poe as a national writer since the influential symbolist poet Charles Baudelaire's translations made Poe's works popular in France in the 1840s. Peeples explains that "by the 1870s it would become a truism among American critics and textbook writers that Poe was more appreciated in Europe than 'at home"' (2004: 10). Since then, efforts to Americanize Poe have been largely successful, for as J. W. Ocker records in his travelogue, Poe-Land: The Hallowed Haunts of 
Edgar Allan Poe, Poe has become part of the urban literary landscape of every major American East-Coast city he ever set foot in, with statues, plaques, and busts of Poe prominently featured alongside other famous 19th century American writers like Washington Irving, Emily Dickenson, Nathaniel Hawthorne, Henry Wadsworth Longfellow, Harriet Beecher Stowe, Ralph Waldo Emerson, Herman Melville, Henry Thoreau, and Walt Whitman. Since Poe's literary works are rarely set in an American location and generally do not deal with specific American topics or characters identified specifically as American, the appropriation of Poe for the national literary canon suggests an 'invented tradition', a term developed by historian Eric Hobsbawn to describe practices "which seek to inculcate certain values and norms..., which automatically implies continuity with the past" (1983: 1). Poe never received such national recognition for his work in his own lifetime. His prominent place today in the libraries, educational institutions, and public places in major American cities alludes to a created 'deep' literary national tradition, which is essentially retrospective. Poe's biographer J. Gerald Kennedy believes that "part of the difficulty of situating Poe within an American tradition derives from the obstinate fact that his writing resists assimilation into the broad interpretive paradigms constructed to define our national literature" (1996: 534). Some critics see such resistance as uniquely American, "a shining example of American individualism" (Peeples 2004: 18). Others see Poe as an overrated eccentric on the literary scene. Renowned AngloAmerican critic T. S. Eliot complained: "The variety and ardor of [Poe's] curiosity delight and dazzle; yet in the end the eccentricity and lack of coherence of his interests tire. There is just that lacking which gives dignity to the mature man: a consistent view of life" (1965: 35). The many interpretations of Poe's relative literary merit allow folklorists to identify a schism between high and low culture, and academic and popular culture, and to detect the tension it creates. Poe-lore draws its energy from this tension and from the continuous debates about Poe's place in American letters.

\section{CONCLUSION}

From a folklore studies perspective, the posthumous appropriation of Poe as one of the greatest national writers reflects the way tradition (invented or otherwise) provides a national conceptual lens through which to view Poe. Simon J. Bonner observes:

Traditions do not carry the deep sense of a localized past as much as broad structural and aesthetic concepts that transcend group and national 
limits. In all the perspectives taken to envision American culture, folklore has been an instrument of grounding. It has consistently provided extra depth to the nation's shallow roots. (2002: 63)

Bonner's analysis of tradition as providing a structural and aesthetic framework within which to filter the American experience can also be applied to understanding the way Poe has become appropriated by popular culture to signify something profound, deep, and unique about the nation. The Poe Legend may also reflect American anxiety about identity and place.

The legends revolving around Poe's death must take into account the emergence of the urban, industrialized mass society with its dizzying pace and alienating social spaces. Today, the folklore of famous people is intimately tied to the proliferation of mass media in virtual space and the social experience of urban space. Poe's literary works reveal great anxiety about the haunting experience of crowds, strangers, and alienation in the city. Significantly, belief narratives illuminate his death within the context of urban space and the gothic themes of his literary works. During his lifetime, Poe strove desperately for literary fame and economic success. Nevertheless, while achieving relative literary fame, in particular the widely circulated poem The Raven, and his short stories, Poe was haunted by ill fame and rumors about his personal conduct and addiction to drugs and alcohol.

Although contemporary legends often deal with the anxieties and desires of everyday life, a considerable body of folk narratives deals with famous historical people and the mysteries, rumors, and anecdotes ascribed to them. Such narratives often draw on the thematic and stylistic conventions of tales of the occult. Contemporary legends reflect the experience, anxieties, and mysteries of urban living, revealing psychosocial and sociological perspectives on gender, identity, and social status within specific urban environments. Poe's short, difficult life and mysterious death have fueled both academic and folkloristic narratives. By straddling literary and popular fame, Poe occupies a dynamic Spielraum in contemporary folklore because his haunted life and mysterious death, similar to the literary conventions for the gothic in literature, collapse 'high' and 'low' culture. The hegemonic boundaries separating literary scholarship and pop culture are contested in Poe-lore, which fuses everyday life with the mysterious and the uncanny. The folklore of famous people is intimately - perhaps even mysteriously - tied to the social experience of urban space, death, disappearance, and the haunting experience of city crowds, strangers, and alienation. In Poe's case, the intertwining of his fiction with his real-life struggles has made Poe scholarship the most biographically centered of any American writer, past or present, and produced Poe not only as a towering legend in American literature, but also as a legendary figure in the popular imagination. 


\section{REFERENCES}

Bennett, Gillian \& Rowbottom, Anne 2009. "Born a Lady, Married a Prince, Died a Saint": The Deification of Diana in the Press and Popular Opinion in Britain. In: M. Kõiva (ed.) Media and Folklore: Contemporary Folklore IV. Tartu: ELM Scholarly Press, pp. 271-287. Available at http://www.folklore.ee/rl/pubte/ee/cf/ cf4/CF4_Bennett_Rowbottom.pdf, last accessed on April 26, 2016.

Blanco, María del Pilar \& Peeren, Esther (eds.) 2010. Popular Ghosts: The Haunted Spaces of Everyday Culture. New York \& London: Continuum.

Bondeson, Jan 2001. Buried Alive: The Terrifying History of Our Most Primal Fear. New York \& London: W. W. Norton \& Company.

Bonner, Simon J. 2002. In Search of American Tradition. In: S. J. Bonner (ed.) Folk Nation: Folklore in the Creation of American Tradition. Wilmington, DE: Scholarly Resources, Inc., pp. 3-70.

Brandy, William T. 1987. Dr. Moran and the Poe-Reynolds Myth. In: B. F. Fisher (ed.) Myths and Reality: The Mysterious Mr. Poe. Baltimore, MD: The Edgar Allan Poe Society, pp. 26-36. Available at http://www.eapoe.org/papers/psbbooks/pb19871d. htm, last accessed on April 26, 2016.

Brunvand, Jan Harold 1999. Too Good to Be True: The Colossal Book of Urban Legends. New York \& London: W. W. Norton \& Company.

Certeau, Michel de 1984. The Practice of Everyday Life. Berkeley \& Los Angeles \& London: University of California Press.

Dégh, Linda 2001. Legend and Belief: Dialectics of a Folklore Genre. Bloomington: Indiana University Press.

Dundes, Alan 1965. What Is Folklore? In: A. Dundes (ed.) The Study of Folklore.Englewood Cliffs, NJ: Prentice-Hall, pp. 1-3.

Eliot, T. S. 1965. To Criticize the Critic and Other Writings. New York: Farrar, Straus, and Giroux.

Goldstein, Diane E. 2004. Once Upon a Virus: AIDS Legends and Vernacular Risk Perception. Logan: Utah State University Press.

Harris, Paul 2007. Fresh Clues Could Solve Mystery of Poe's Death. The Guardian, October 21. Available at http://www.theguardian.com/world/2007/oct/21/books. booksnews, last accessed on April 26, 2016.

Hobsbawn, Eric 1983. Introduction: Inventing Traditions. In: E. Hobsbawn \& T. Ranger (eds.) The Invention of Tradition. Cambridge: Cambridge University Press, pp. 1-14.

Hopkins, Robert 2007. The Mysterious Disappearance and Death of Edgar A. Poe. The Southern Quarterly, Vol. 44, No. 4, pp. 41-60. Available at http://0-literature. proquest.com.fama.us.es/searchFulltext.do?id=R04012090\&divLevel=0\&area=a bell\&forward=critref_ft, last accessed on April 26, 2016.

Kennedy, J. Gerald 1996. The Violence of Melancholy: Poe against Himself. American Literary History, Vol. 8, No. 3, pp. 533-551. http://dx.doi.org/10.1093/alh/8.3.533.

Kennedy, J. Gerald 2001. Edgar Allan Poe, 1809-1849: A Brief Biography. In: J. Gerald Kennedy (ed.) A Historical Guide to Edgar Allan Poe. Oxford: Oxford University Press, pp. 19-62. 
Knowing Poe 2002. Available at http://knowingpoe.thinkport.org/library/news/toaster. asp, last accessed on April 26, 2016.

Life Expectancy 2007 = Life Expectancy by Age, 1850-2011. InfoPlease: U.S. Statistics. Available at http://www.infoplease.com/ipa/A0005140.html, last accessed on April 26, 2016.

Ljungquist, Kent P. 2002. The Poet as Critic. In: K. J. Hayes (ed.) The Cambridge Companion to Edgar Allan Poe. Cambridge: Cambridge University Press, pp. 7-21.

Møllegaard, Kirsten 2005. The Fairy-Tale Paradigm: Contemporary Legend on Hans Christian Andersen's Parentage. Contemporary Legend, Vol. 8, pp. 28-46.

Museum 2014 = The Museum of Edgar Allan Poe. Available at http://www.poemuseum. org/, last accessed on April 26, 2016.

Neimeyer, Mark 2002. Poe and Popular Culture. In: K. J. Hayes (ed.) The Cambridge Companion to Edgar Allan Poe. Cambridge: Cambridge University Press, pp. 205225.

Neyfakh, Leon 2007. Poe's Mysterious Death: The Plot Thickens! The Observer, October 16. Available at http://observer.com/2007/10/poes-mysterious-death-theplot-thickens/, last accessed on April 26, 2016.

Ocker, J. W. 2015 [2014]. Poe-Land: The Hallowed Haunts of Edgar Allan Poe. Woodstock, VT: The Countryman Press.

OED 1989 = Oxford English Dictionary, edited by J. A. Simpson \& E. S. C. Weiner. 2nd edition. Oxford: Clarendon Press.

Peeples, Scott 2004. The Afterlife of Edgar Allan Poe. Rochester, NY: Camden House.

Poe, Edgar Allan 2004a [1840]. The Man of the Crowd. In: G. R. Thompson (ed.) The Selected Writings of Edgar Allan Poe. New York: W. W. Norton \& Company, pp. 232-239.

Poe, Edgar Allan 2004b [1845]. The Black Cat. In: G. R. Thompson (ed.) The Selected Writings of Edgar Allan Poe. New York: W. W. Norton \& Company, pp. 348-356.

Poe, Edgar Allan 2004c [1845]. The Premature Burial. In: G. R. Thompson (ed.) The Selected Writings of Edgar Allan Poe. New York: W. W. Norton \& Company, pp. 356-367.

Poe, Edgar Allan 2004d [1845]. The Imp of the Perverse. In: G. R. Thompson (ed.) The Selected Writings of Edgar Allan Poe. New York: W. W. Norton \& Company, pp. 401-407.

Poe, Edgar Allan 2004e [1845]. The Philosophy of Composition. In: G. R. Thompson (ed.) The Selected Writings of Edgar Allan Poe. New York: W. W. Norton \& Company, pp. 675-684.

Rojek, Chris 2001. Celebrity. London: Reaktion Books.

Ruebsaat, Norbert 2007. Seen by Many: The Celebrity Image. In: Brian Howell (ed.) Fame Us: Celebrity Impersonators and the Cult(ure) of Fame. Vancouver: Arsenal Pulp Press, pp. 9-24.

Silverman, Kenneth 1991. Edgar A. Poe: Mournful and Never-Ending Remembrance. New York: HarperCollins.

Society n.d. = The Edgar Allan Poe Society of Baltimore. Available at http://www.eapoe. org/index.htm, last accessed on April 26, 2016.

Thomas, Dwight \& Jackson, David K. 1987. The Poe Log: A Documentary Life of Edgar Allan Poe 1809-1849. New York: G. K. Hall \& Company. 
Toelken, Barre 1996. The Dynamics of Folklore. Logan, UT: Utah State University Press.

TripAdvisor 2015 = Edgar Allan Poe's Grave Site and Memorial. Available at http:// www.tripadvisor.com/Attraction_Review-g60811-d144278-Reviews-Edgar_Allan_ Poe_s_Grave_Site_and_Memorial-Baltimore_Maryland.html, last accessed on April 26, 2016.

Vergil 2008. The Aeneid. Trans. by Sarah Ruden. New Haven, CT: Yale University Press.

Walsh, John Evangelist 1999. Midnight Dreary: The Mysterious Death of Edgar Allan Poe. Brunswick, NJ: Rutgers University Press. 